Artykuł jest dostępny na zasadzie dozwolonego użytku osobistego. Dalsze rozpowszechnianie (w tym umieszczanie w sieci) jest zabronione i stanowi poważne naruszenie przepisów prawa autorskiego oraz grozi sankcjami prawnymi.

PAULINA POTOCKA | DOROTA ROŻKIEWICZ | ELŻBIETA OŁDAK

\title{
HIGIENA RĄK WŚRÓD PERSONELU MEDYCZNEGO - CO JESZCZE MOŻNA ZROBIĆ
}

\author{
HAND HYGIENE AMONG HEALTHCARE PERSONNEL - WHAT ELSE WE CAN DO
}

STRESZCZENIE: Higiena rąk jest postrzegana jako najprostsza, a zarazem najważniejsza metoda zapobiegania infekcjom w oddziałach szpitalnych. Pomimo tego wskaźnik przestrzegania wytycznych higieny rąk wśród pracowników ochrony zdrowia, a szczególnie wśród lekarzy, pozostaje na niskim poziomie. W ostatnich latach przeprowadzono wiele kampanii promujących higienę rąk. Mimo intensywnych starań wskaźnik przestrzegania higieny rąk - po początkowej poprawie - wciąż pozostaje na niskim poziomie. Dokonano analizy czynników mogących mieć wpływ na to zjawisko, takich jak: brak wiedzy naukowej, przepracowanie, zmęczenie kampaniami itp. Szczególnie podkreślono rolę indywidualnego zachowania, złych nawyków oraz etycznego kryzysu wśród pracowników ochrony zdrowia, które mogą być odpowiedzialne za nieprzestrzeganie higieny rąk podczas opieki nad pacjentem.

SŁOWA KLUCZOWE: etyka, higiena rąk, kampanie promujące, negatywne czynniki, personel medyczny, wskaźnik przestrzegania higieny rąk

ABSTRACT: Hand hygiene has been identified as one of the simplest, but most important, methods to prevent cross-infection in healthcare facilities. In spite of this fact, the hand hygiene compliance rate remains low among healthcare workers, especially among physicians. In recent years a lot of promotional campaigns for hand hygiene were performed. Despite these intensive efforts compliance about hand hygiene after initial improved is still poor. We investigated factors associated with this phenomenon, such as lack of scientific information, overwork, campaign fatigue etc. We want to emphasize the role of individual behavior, bad habits of employees and an ethical crisis among healthcare workers in low hand hygiene compliance during patient care.

KEY WORDS: ethics, hand hygiene, hand hygiene compliance, healthcare workers, negative factors, promotional campaigns

\section{WSTĘP}

Zakażenia szpitalne (ang. healthcare-associated infections - HAI) stanowią jedną z głównych przyczyn zgonów oraz zwiększonej chorobowości wśród hospitalizowanych pacjentów. W krajach rozwiniętych HAI dotyczą od 5 do 15\% hospitalizacji [1]. Przykładowo w 2011 roku w Stanach Zjednoczonych zakażenia szpitalne odnotowano wśród 721800 pacjentów, z tej grupy podczas pobytu w szpitalu zmarło 75000 [2]. W Europie co roku około 4100000
Klinka Obserwacyjno-Zakaźna Dzieci

Uniwersytetu Medycznego w Białymstoku

". DOROTA ROŻKIEWICZ

Uniwersytecki Dziecięcy Szpital Kliniczny

w Białymstoku,

ul. Jerzego Waszyngtona 17,

15-274 Białystok,

Tel./Fax: (85) 74506 85,

e-mail: dorota.rozkiewicz@umb.edu.pl

Wpłynęło: 25.08.2016

Zaakceptowano: 12.09 .2016

DOl: dx.doi.org/10.15374/FZ2016050 osób nabywa HAI, u 37000 są one bezpośrednią przyczyną zgonów, a pośrednio mogą przyczynić się do śmierci 110000 pacjentów [3]. Zakażenia szpitalne skutkują wydłużeniem pobytu w szpitalu, a co za tym idzie - wzrostem kosztów ponoszonych przez placówki opieki zdrowotnej. W 2011 roku rząd Stanów Zjednoczonych wydał z tego powodu około 35 miliardów dolarów, natomiast w Europie roczne wydatki szacuje się na 13-24 miliardów euro $[1,4]$.

Szczególnie narażeni na rozwój HAI są hospitalizowani pacjenci $\mathrm{z}$ ciężkimi chorobami podstawowymi, 
Artykuł jest dostępny na zasadzie dozwolonego użytku osobistego. Dalsze rozpowszechnianie (w tym umieszczanie w sieci) jest zabronione i stanowi poważne naruszenie przepisów prawa autorskiego oraz grozi sankcjami prawnymi.

przebywający w oddziałach intensywnej opieki, wśród których aż około $30 \%$ nabywa infekcje związane $\mathrm{z}$ pobytem w szpitalu [5]. Przyczyną większości zakażeń jest przenoszenie drobnoustrojów za pośrednictwem rąk personelu medycznego. Jest to także główna droga transmisji szczepów wielolekoopornych (ang. multi-drug resistant organisms - MDRO), które stanowią duże ryzyko dla pacjentów i pracowników ze względu na ograniczoną liczbę antybiotyków dostępnych w leczeniu oraz brak możliwości tworzenia nowych antybiotyków w przyszłości [6].

Najprostszą i najskuteczniejszą metodą zapobiegania HAI jest prawidłowa higiena rąk, której promocja jest obecnie traktowana jako ogólnoświatowy priorytet $\mathrm{w}$ walce $\mathrm{z}$ zakażeniami szpitalnymi. W krajach rozwiniętych infrastruktura placówek medycznych jest na wysokim poziomie. Placówki te mają praktycznie nieograniczony dostęp do środków odkażających, materiałów promocyjnych i szkoleniowych. W szpitalach powstają komisje kontroli zakażeń, które dostarczają istotnych informacji zwrotnych. Mimo tych wszystkich środków, wskaźnik zgodności przestrzegania higieny rąk w stosunku do zaleceń wciąż jest w wielu miejscach bardzo niski.

Wydaje się, że zawodzi zarówno najważniejszy, jak i najmniej przewidywalny czynnik - czynnik ludzki. Zadziwiające jest, że mimo wielu kampanii promocyjnych, ogólnej świadomości i wiedzy na ten temat, higiena rąk jest wciąż często pomijana przez większość pracowników opieki zdrowotnej.

\section{HISTORIA}

Do drugiej połowy XIX wieku i rewolucyjnych odkryć Ludwika Pasteura oraz Roberta Kocha, uznawanych za twórców mikrobiologii, powstawanie chorób i sposób ich szerzenia się pozostawały jedynie w sferze domysłów. W tych czasach, a dokładnie w 1861 roku, doktor Ignaz Semmelweis po raz pierwszy postawił hipotezę dotyczącą przenoszenia drobnoustrojów za pośrednictwem rąk pracowników medycznych i wprowadził zalecenie mycia rąk w praktyce klinicznej. Podczas trzymiesięcznego okresu obserwacji zaobserwował u pacjentek spadek śmiertelności spowodowanej posocznicą połogową wywołaną przez Streptococcus pyogenes - z 5-30\% do 1-2\%. Udowodnił, że za transmisję patogenów odpowiedzialne były skażone ręce pracowników. Dzięki swoim spostrzeżeniom zainicjował naukowe podejście do kontroli infekcji. Początkowo doniesienia te spotkały się z negatywnym odbiorem w świecie medycznym, jednak wkrótce higiena rąk stała się podstawowym elementem nie tylko opieki nad pacjentami, lecz także kultury. Przykładem jest chociażby Światowy Dzień Mycia Rąk, czyli święto obchodzone corocznie 15 października, ustanowione przez UNICEF w 2008 roku jako akcja, której celem jest globalna edukacja na temat mycia rąk [7].
Od badań Semmelweisa minęło ponad 150 lat. Nastąpił znaczny rozwój mikrobiologii lekarskiej i nikt nie ma wątpliwości odnośnie transmisji drobnoustrojów. Mimo ogólnej świadomości - zarówno wśród pracowników ochrony zdrowia, jak i pacjentów - zakażenia szpitalne wciąż stanowią istotny problem oraz jedno z głównych wyzwań współczesnej medycyny.

Pod koniec XX wieku w kilku państwach zostały zorganizowane kampanie promujące prawidłową higienę rąk. W latach 1994-1997 ocenianych było 7 szpitali w Szwajcarii, w 1996 roku przeprowadzono ogólnopaństwową kampanię we Francji (która objęła 830 szpitali), w Wielkiej Brytanii natomiast pierwszy narodowy program rozpoczęto w 1980 roku, zaś drugi w latach 1993-1994 [8-10]. Dzięki przeprowadzeniu tych akcji uzyskano wiele interesujących danych, wciąż jednak brakowało ujednolicenia wytycznych, sposobu przeprowadzania oraz oceny programów. Pionierską inicjatywą były opublikowane w 2002 roku przez CDC (ang. Centers for Disease Control and Prevention) pierwsze wytyczne, mające na celu poprawę jakości higieny rąk. Kolejnej próby podjęli się badacze zespołu Pierwszej Światowej Inicjatywy na rzecz Bezpieczeństwa Pacjenta [11]. W 2005 roku WHO (ang. World Health Organization) zainicjowało ogólnoświatową strategie „Clean Care is Safer Care” (Czysta opieka jest bezpieczną opieką), opartą na 5 podstawowych elementach, takich jak: zmiany systemowe, szkolenie i edukacja, ewaluacja i informacja zwrotna dla personelu, przypomnienia w miejscu pracy i bezpieczeństwo instytucjonalne. W latach 20062008 WHO wprowadziło testową, wielokierunkową strategię higieny rąk w 8 pilotażowych miejscach, w 6 regionach świata, uwzględniając różnice kulturowe i różnice w rozwoju danych miejsc (Bangladesz, Kostaryka, Chiny, Włochy, Mali, Pakistan oraz dwa ośrodki w Arabii Saudyjskiej). Inne cele i wyzwania były postawione przykładowo w Bangladeszu, gdzie trzeba było zacząć przede wszystkim od zmian $\mathrm{w}$ infrastrukturze, bez których kolejne kroki były niemożliwe (np.: zapewnienie dostępu do bieżącej, czystej wody, zaopatrzenie ośrodka w produkowany lokalnie, tani płyn odkażający na bazie alkoholu). Natomiast we Włoszech, gdzie w programie brały udział oddziały posiadające już system nadzoru HAI, ulepszenia polegały głównie na zmianie dotychczasowych przyzwyczajeń pracowników służby zdrowia poprzez narzędzia WHO: drukowane materiały, gadżety, interaktywne dyskusje, kursy treningowe, wdrożenie platformy internetowej itp. [12]. Na podstawie doświadczeń wynikających z tej akcji w 2009 roku ponad 100 międzynarodowych ekspertów opracowało „Wytyczne WHO dotyczące higieny rąk w opiece zdrowotnej” oraz kontynuowało strategie „Clean Care is Safer Care” w celu pomocy zakładom opieki zdrowotnej w stosowaniu zaleceń w codziennej pracy. Od 2005 roku do chwili obecnej 139 państw zobowiązało się do poprawy higieny rąk poprzez wdrażanie programów profilaktycznych, część $\mathrm{z}$ nich rozpoczęła kampanie na skalę ogólnokrajową $[1,13]$. 

(w tym umieszczanie w sieci) jest zabronione i stanowi poważne naruszenie przepisów prawa autorskiego oraz grozi sankcjami prawnymi.

Od 7 stycznia 2013 roku do tego grona dołączyła również Polska, a w akcję zaangażowały się 93 szpitale w całym kraju [14]. W wytycznych opublikowano przejrzyste zasady postępowania dla pracowników oparte na programie „5 momentów higieny rąk”, w którym od personelu wymaga się, by mył i/lub odkażał ręce w następujących sytuacjach: przed kontaktem z pacjentem, przed przystąpieniem do czystych procedur, po narażeniu na kontakt $\mathrm{z}$ płynami ustrojowymi, po kontakcie $\mathrm{z}$ pacjentem, po kontakcie $\mathrm{z}$ otoczeniem pacjenta. Wytyczne oraz narzędzia do ich wdrażania są ogólnodostępne i promowane przez WHO. Wskaźnik higieny rąk z założenia powinien być bliski $100 \%$, a HAI zredukowane do minimum. Jednak po 7 latach od tej publikacji wiadomo, że tak nie jest, a wielu działaczy na rzecz kontroli infekcji wciąż próbuje odnaleźć przyczynę tego stanu rzeczy.

\section{KAMPANIE PROMUJĄCE HIGIENĘ RĄK}

Lekarze, pielęgniarki oraz inni członkowie personelu medycznego za pośrednictwem rąk mogą przenosić z pacjenta na pacjenta drobnoustroje, które kolonizują ich skórę. Do przeniesienia patogenów może dojść również za pośrednictwem zanieczyszczonego środowiska, które otacza pacjenta. Wykazano, że mikroorganizmy są zdolne do przeżycia na rękach nawet kilka minut po kontaminacji. Jednorazowy kontakt wiąże się ze skażeniem 4-16\% powierzchni dłoni i przy kolejnych kontaktach bez zastosowania dezynfekcji wzrasta nawet do $40 \%[15,16]$. Ręce pracowników medycznych są uznawane za główną drogę transmisji patogenów w środowisku szpitalnym, dlatego przestrzeganie higieny rąk jest tak ważne. Istnieje wiele sposobów oceny przestrzegania higieny rąk przez pracowników opieki medycznej, takich jak: bezpośrednia obserwacja, kwestionariusze dotyczące samooceny lub wiedzy, pomiar zużycia środków służących do odkażania rąk czy też elektroniczne urządzenia instalowane przy stanowiskach pracy [17]. Nie ma jednak standaryzowanego sposobu oceny i żadna $\mathrm{z}$ tych metod nie jest doskonała poprzez swój subiektywny charakter, wysokie koszty czy też zmianę zachowania pracowników podczas obserwacji. Głównie z tych względów w latach 2000-2012, w trakcie 36 kampanii prowadzonych w 20 europejskich krajach, tylko $50 \%$ akcji zostało ocenionych pod względem skuteczności, z czego tylko w 55\% z nich skorzystano $\mathrm{z}$ udostępnionych przez WHO narzędzi [18]. Wśród ośrodków na całym świecie, które zdecydowały się na pomiar wskaźnika zgodności przestrzegania higieny rąk wśród pracowników, uzyskano niepokojące dane związane z bardzo niskim wskaźnikiem - wynoszącym 40\% - co jest absolutnie niedopuszczalnie niską wartością w XXI wieku [19].

Zostało udowodnione, że wielokierunkowe kampanie przynoszą korzyści i wpływają na redukcję liczby zakażeń szpitalnych oraz wzrost wskaźnika przestrzegania higieny rąk. Przykładowo w trakcie dwuletniej kampanii WHO (2004-2006), przeprowadzonej w 8 pilotażowych miejscach $\mathrm{w}$ różnych regionach świata, średnia zgodność wzrosła z 39,6 do 56,9\% w trakcie trwającej trzy miesiące interwencji. W wysoko rozwiniętych krajach średnia ta wzrosła z 54,3 do 68,5\%, a w krajach rozwijających się - z 22,4 do $46,1 \%$. Zgodnie z oczekiwaniami wpływ interwencji był większy w krajach rozwijających się, które startowały z dużo niższego poziomu, gdzie wcześniej nie było dostępu do wiedzy oraz podstawowych środków ochrony. Wynik ten był bardzo zachęcający, ponieważ poprzez wprowadzenie prostych i niedrogich rozwiązań szybko uzyskano dobre rezultaty. Wzrost o 12,2\% w krajach bogatych oczywiście również jest traktowany jako sukces znacząco wpływający na redukcję zakażeń szpitalnych, jednak wciąż wiele brakuje do oczekiwanych 100\% [12]. Podobnie sytuacja przedstawiała się $\mathrm{w}$ innych krajach rozwiniętych. Rezultatem trzyletniej (opartej na strategii WHO) kampanii w Niemczech, rozpoczętej w 2008 roku, był wzrost o 11\%, ze startowego poziomu 60,9\%. Podczas akcji we Włoszech uzyskano wzrost z 55\% do 69\%, w Belgii 20\% - z 49\% do 69\% $\mathrm{w}$ pierwszym roku prowadzenia programu (w trzecim roku z 58 do 69\%), natomiast w Australii odnotowano wzrost z 43,6 do $67,8 \%$ [20]. W niektórych pracach przedstawiano imponujące wyniki, przykładowo wzrost wskaźnika zgodności z $89 \%$ do $100 \%$ po miesiącu trwania edukacji na oddziale intensywnej opieki noworodków (OITN) w Stanach Zjednoczonych. Jednak trzeba wziąć pod uwagę, że oceniana była tylko interwencja przed wejściem na oddział, z pominięciem pozostałych momentów, w których mycie rąk było również wymagane ( 5 momentów higieny rąk). Na wynik wpłynął na pewno także krótki czas, po którym dokonywano oceny [21]. Mimo wprowadzonych interwencji - zawierających 5 głównych elementów wielotorowej strategii uwzględniającej: zmiany systemowe, czyli rozwiniętą infrastrukturę zapewniającą nieograniczony dostęp do wody i taniego środka odkażającego na bazie alkoholu (ang. alcohol based hand rub - ABHR), szkolenia i edukację, przekazywanie informacji zwrotnych dla personelu, umieszczanie przypomnień w miejscu pracy i zapewnienie wsparcia przez organy rządzące na poziomie krajowym i instytucjonalnym - wskaźnik przestrzegania higieny rąk jest wciąż na zbyt niskim poziomie.

\section{CZYNNIKI WPŁYWAJĄCE NA BRAK PRZESTRZEGANIA HIGIENY RĄK}

Ze względu na przedstawione powyżej dane i wiele innych źródeł potwierdzających brak przestrzegania higieny przez pracowników opieki zdrowotnej, wielu autorów rozpoczęło poszukiwania przyczyny tego zjawiska. Często po wstępnej poprawie w wyniku szpitalnej lub ogólnokrajowej kampanii, 


\section{oraz grozi sankcjami prawnymi.}

wskaźnik zgodności ponownie spadał, wskazując na ciągłą potrzebę podkreślania istoty kontroli infekcji. Było tak np. podczas kampanii w Belgii (gdzie początkowo odnotowano wzrost z 49 do $69 \%$ po jednym roku trwania interwencji, lecz po trzech latach spadł on do $58 \%$, a po kontynuowaniu działań promocyjnych wzrósł ponownie tylko do 69\%) lub podczas akcji w Stanach Zjednoczonych (gdzie zauważono powrót do stanu wyjściowego już po trzech miesiącach obserwacji na OITN) [20, 21]. Ciekawe wnioski uzyskano w wyniku obserwacji kampanii w Hongkongu (w latach 2007-2008, a następnie w latach 2009-2011), gdzie zauważono zmęczenie akcją promującą higienę rak. Początkowy optymistyczny wzrost w pierwszym roku inicjatywy (z 41\% do 58\%) nie utrzymał się mimo ciągłego prowadzenia działań w kolejnych latach, a wskaźnik przestrzegania higieny rąk był na stałym poziomie 50\%. By sprostać wyzwaniu i poprawić przestrzeganie higieny rąk, autorzy projektu opracowali nową strategię: zaangażowano pielęgniarki epidemiologiczne do przypominania o potrzebie higieny rąk lekarzom podczas sytuacji klinicznych, organizowano indywidualne konkursy z nagrodami (np. na najlepszy promujący plakat) i wprowadzano codzienną kontrolę. Uzyskano imponujący wzrost wskaźnika do $83 \%$ po sześciomiesięcznym okresie oceny [22]. Wynik ponownej interwencji był zadowalający, jednak konieczna jest ciągła edukacja i przypominanie o potrzebie mycia rąk, co jest zjawiskiem niepokojącym wśród wykształconego personelu opieki medycznej.

Jak wskazuje się w zaleceniach WHO, poprawa higieny rąk powinna opierać się na wielotorowej interwencji. Działania skupiające się głównie na edukacji i poprawie warunków środowiskowych przynoszą niestety rezultaty na niewystarczającym poziomie. Istotne są również przekonania oraz osobiste podejście personelu ochrony zdrowia, często też wynikające $\mathrm{z}$ niewiedzy. Wielu pracowników jest przekonanych, że używanie rękawic zwalnia z obowiązku dezynfekcji rąk oraz że odkażające środki na bazie alkoholu działają bardziej wysuszająco i uszkadzająco na skórę niż mycie wodą z mydłem [1]. Dotychczasowe badania wskazują, że wielu pracowników wierzy w rolę higieny rąk w redukcji zakażeń szpitalnych i w ankietach dotyczących samooceny zgłaszają wysoki poziom przestrzegania higieny rąk, co jednak nie zawsze przenosi się na obserwacje prowadzone w trakcie pracy oraz na obserwacje bezpośrednie. Przykładowo podczas badania w szpitalu w New Delhi wiedza uczestników odnośnie higieny rąk była zgłaszana w 86,8\%, ale rzeczywista zgodność oceniona $\mathrm{w}$ trakcie bezpośredniej obserwacji była mniejsza i wynosiła 75,1\% [23]. Biorąc to pod uwagę, w wielu pracach podkreślano: brak czasu podczas pracy w szpitalu, zbyt dużą ilość obowiązków przypadającą na pracowników ochrony zdrowia, braki kadrowe i przeludnienie oddziałów szpitalnych [24-27]. Stanowi to na pewno istotny element braku zgodności, jednak należy się zastanowić, czy - biorąc pod uwagę bezpieczeństwo i życie pacjentów - może stanowić wystarczającą wymówkę. Trzeba podkreślić, że procedura dezynfekcji rąk jest prosta i szybka, a do zabicia większości bakterii na dłoniach wystarczy tylko 20 sekund prawidłowo przeprowadzonej higieny rąk, opartej na schemacie Ayliffe'a $[1,16]$.

W wielu pracach zwracano uwagę, że im wyższy status pracownika ochrony zdrowia, tym przestrzeganie higieny rąk jest niższe. Nie jest tajemnicą, że w tej dziedzinie pielęgniarki mają dużo lepsze wyniki niż lekarze [28, 29]. Słabsze wyniki w tym zakresie obserwuje się u chirurgów, anestezjologów oraz pracowników oddziałów intensywnej opieki, a więc specjalistów, którzy powinni najbardziej dbać o higienę rąk ze względu na ciężki stan pacjentów i tym samym większe narażenie na ryzyko nabycia HAI. Biorąc pod uwagę te dane zastanawia fakt, czy higiena rąk nie jest często pomijana ze względu na prostotę i ważniejsze obowiązki wobec chorych [7].

Na przestrzeganie higieny rąk składa się wiele elementów, takich jak czynniki motywacyjne (wpływ społeczeństwa, a szczególnie wzorzec postępowania wśród kolegów i przełożonych, osobista ochrona, wykorzystywanie wskazówek, np. przypominających plakatów na ścianach) oraz udogodnienia środowiskowe (łatwy dostęp do informacji, wiedza, organizacja i kultura pracy). Ludzkie zachowania są bardzo skomplikowane, a odnalezienie bezpośredniej przyczyny obecnego stanu rzeczy jest wyzwaniem również dla nauk z dziedziny psychologii. Zaczęto się zastanawiać, czy lenistwo i etyczna luka w zachowaniu pracowników ochrony zdrowia nie leżą u podłoża nieprzestrzegania higieny rąk [7, 30, 31]. Mortell i wsp. w swojej pracy zasugerowali moralny upadek personelu medycznego, $\mathrm{z}$ powodu którego dobro pacjenta nie jest stawiane na pierwszym miejscu [7]. Autorzy podkreślają, że pomimo: ogólnego podejścia, zgodnie z którym higiena rąk jest integralną częścią kultury, powszechnie dostępnej wiedzy opartej na dowodach naukowych, ogromnych nakładów finansowych, licznych kampanii promocyjnych oraz nacisków ogólnoświatowych autorytetów (takich jak WHO czy CDC), wciąż odnotowuje się brak przestrzegania higieny rąk przez wykształconych i doświadczonych pracowników ochrony zdrowia. Zatrważające jest, że wiedza na temat prostej procedury ratującej życie musi być ciągle przypominana i powtarzana. Przepracowanie, zbyt duża ilość obowiązków lub zwykłe zapominanie nie są usprawiedliwieniem - biorąc pod uwagę prostotę i ogólną dostępność higieny rąk, tym bardziej, że celem jest ochrona pacjentów przed transmisją patogenów odpowiedzialnych za niezwykle niebezpieczne dla ich życia zakażenia szpitalne. Autorzy podkreślają rolę lekarzy i innych zawodów medycznych jako rzeczników praw pacjenta i uczulają na potrzebę wzmocnienia koncepcji obowiązku moralnego w celu poprawy praktyki higieny rąk, niezależnie od osobistych poglądów, podkreślając konieczność dalszej obserwacji tych spostrzeżeń [7]. 

(w tym umieszczanie w sieci) jest zabronione i stanowi poważne naruszenie przepisów prawa autorskiego oraz grozi sankcjami prawnymi.

\section{PODSUMOWANIE}

Pomimo prowadzenia akcji edukacyjnych i ciągłego rozwoju infrastruktury szpitali, higiena rąk może być wciąż na niskim poziomie - jeśli razem $z$ tymi zmianami nie pójdą zmiany w zachowaniu i w kompleksowym podejściu do pacjenta, mającym na uwadze przede wszystkim jego bezpieczeństwo. Wielu autorów zwraca uwagę na istotny wpływ wzorców, jakimi są koledzy i bezpośredni przełożeni oraz na instytucjonalny klimat wpływający na bezpieczeństwo i dobrą atmosferę pracy. Może - według powiedzenia „czym skorupka za młodu nasiąknie” - już wśród studentów kierunków medycznych asystenci (jako osoby dające przykład) powinni zwracać szczególną uwagę na temat higieny rąk. W trakcie zajęć ze studentami powinno się nie tylko przekazywać wiedzę na temat prawidłowej higieny rąk i niebezpieczeństw związanych z HAI, lecz także rozwijać przyzwyczajenia, ze szczególnym zwróceniem uwagi na etyczny i moralny obowiązek stosowania standardowych środków ochrony podczas opieki nad pacjentem. Biorąc pod uwagę złożoność procesu zmiany zachowania, trzeba rozważyć wprowadzanie innowacyjnych metod opartych na środowiskowej psychologii, naukach behawioralnych, a być może nawet na systemie finansowych kar i nagród. Wcześniejsze interwencje już na poziomie akademickim mogą ułatwić to postępowanie, jednak wymagane są dalsze badania w tym kierunku, oparte na dowodach naukowych $[4,7]$.

\section{KONFLIKT INTERESÓW: nie zgłoszono.}

\section{PIŚMIENNICTWO}

1. World Health Organization. WHO guidelines on hand hygiene in health care. WHO (online) 2009; http://www.who.int/gpsc/5may/tools/9789241597906/en/

2. Centers for Disease Control and Prevention. Healthcare-associated infections. CDC (online) 2016; http://www.cdc.gov/hai/surveillance/

3. European Centre for Disease Prevention and Control. Healthcare-associated infections. ECDC (online); http://ecdc.europa.eu/en/healthtopics/Healthcare-associated_infections/Pages/index.aspx

4. Neo JR, Sagha-Zadeh R, Vielemeyer O, Franklin E. Evidence-based practices to increase hand hygiene compliance in health care facilities: an integrated review. Am J Infect Control 2016;44(6):691-704.

5. World Health Organization. The burden of endemic health care-associated infection worldwide. WHO (online); http://www.who.int/gpsc/country_work/burden_hcai/en/

6. World Health Organization. Evidence of hand hygiene to reduce transmission and infections by multi-drug resistant organism in health-care settings. WHO (online); www.who.int/gpsc/5may/MDRO literature-review.pdf

7. Mortell M, Balkhy HH, Tannous EB, Jong MT. Physician'defiance'towards hand hygiene compliance: is there a theory-practice-ethics gap? I Saudi Heart Assoc 2013;25(3):203-208

8. Pittet $D$, Hugonnet $S$, Harbarth $S$ et al. Effectiveness of a hospital-wide programme to improve compliance with hand hygiene. Infection control programme. Lancet 2009;356(9238):1307-1312.
9. Astagneau P, Branger B, Dumartin C et al. Prevalence of nosocomial infections in France: results of the nationwide survey in 1996. The French Prevalence Survey Study Group. J Hosp Infect 2000:46(3):186-193.

10. Emmerson AM, Enstone JE, Griffin M, Kelsey MC, Smyth ET. The Second National Prevalence Survey of Infection in iospitals-overview of the results. J Hosp Infect 1996;32(3):175-190.

11. Pittet D, Allegranzi B, Storr J, Donaldson J. "Clean care is safer care": the global patient safety challenge 2005-2006. Int J Infect Dis 2006;(10)6):419-424.

12. Allegranzi B, Gayet-Ageron A, Damani N et al. Global implementation of WHO's multimodal strategy for improvement of hand hygiene: a quasi-experimental study. Lancet Infect Dis 2013;13(10):843-851.

13. World Health Organization. Clean care is safer care. WHO (online); http:// www.who.int/gpsc/statements/en/

14. Centrum Monitorowania Jakości w Ochronie Zdrowia. Higiena rąk to bezpieczna opieka; http://www.cmj.org.pl/clean-care/

15. Pittet $D$, Allegranzi B, Sax H. Evidence-based model for hand transmission during patient care and the role of improved practices. Lancet Infect Dis 2006:6(10):641-652.

16. Rożkiewicz D. Ręce personelu jako potencjalne źródło zakażeń szpitalnych. Zakażenia 2011;5:6-12.

17. Jarrin Tejada C, Bearman G. Hand hygiene compliance monitoring: the state of the art. Curr Infect Dis Rep 2015:17(4):470.

18. Latham JR, Magiorakos AP, Monnet DL et al. The role and utilisation of public health evaluations in Europe: a case study of national hand hygiene campaigns. BMC Public Health 2014;14:131.

19. O'Reilly K, Ruokis S, Russell K et al. Standard work for room entry: linking lean, hand hygiene, and patient-centeredness. Healthc (Amst) 2016:4(1):45-51.

20. Reichardt $C$, Königer $D$, Bunte-Schönberger $K$ et al. Three years of national hand hygiene campaign in Germany: what are the key conclusions for clinical practice? J Hosp Infect 2013;83(Suppl. 1):S11-S16.

21. Raskind $\mathrm{CH}$, Worley S, Vinski J, Goldfarb J. Hand hygiene compliance rates after an educational intervention in a neonatal intensive care unit. Infect Control Hosp Epidemiol 2007:28(9):1096-1098.

22. Seto WH, Yuen SW, Cheung CW, Ching PT, Cowling BJ, Pittet D. Hand hygiene promotion and the participation of infection control link nurses: an effective innovation to overcome campaign fatigue. Am J Infect Control 2013;41(12):1281-1283

23. Jain M, Dogra V, Mishra B, Thakur A, Loomba SP. Infection control practices among doctors and nurses in a tertiary care hospital. Ann Trop Med Publ Health 2012:5(1):29-33.

24. Sax H, Uçkay I, Richet H, Allegranzi B, Pittet D. Determinants of good adherence to hand hygiene among healthcare workers who have extensive exposure to hand hygiene campaigns. Infect Control Hosp Epidemiol 2007:28(11):1267-1274.

25. Pittet D, Simon A, Hugonnet S, Pessoa-Silva CL, Sauvan V, Perneger TV. Hand hygiene among physicians: performance, beliefs, and perceptions. Ann Intern Med 2004;141(1):1-8

26. Nicol PW, Watkins RE, Donovan RJ, Wynaden D, Cadwallader H. The power of vivid experience in hand hygiene compliance. J Hosp Infect 2009:72(1):36-42

27. Joshi SC, Diwan V, Tamhankar AJ et al. Qualitative study on perceptions of hand hygieneamong hospital staff in a rural teaching hospital in India. J Hosp Infect 2012:80(4):340-344.

28. Venier AG, Zaro-Goni D, Pefau Met al. Performance of hand hygiene in 214 healthcare facilities in South-Western France. J Hosp Infect 2009;71(3):280-282.

29. Mahfouz AA, Al-Zaydani IA, Abdelaziz AO, El-Gamal MN, Assiri AM. Changes in hand hygiene compliance after a multimodal intervention among healthcare workers from intensive care units in Southwestern Saudi Arabia. J Epidemiol Glob Health 2014;4(4):315-321.

30. McLaws ML, Farahangiz S, Palenik CJ, Askarian M. Iranian healthcare workers' perspective on hand hygiene: a qualitative study. J Infect Public Health 2015:8(1):72-79.

31. Smiddy MP, O'Connell R, Creedon SA. Systematic qualitative literature review of health care workers' compliance with hand hygiene guidelines. Am J Infect Control 2015;43(3):269-274. 